\title{
The Oil Policies \\ of the Gulf Arab Nations
}

\author{
RONALD D. RIPPLE \\ RONALD E. HAGEN
}

Program on Resources: Energy and Minerals

East-West Center

Honolulu, Hawaii

\section{DISCLAIMER}

This report was prepared as an account of work sponsored by an agency of the United States Government. Neither the United States Government nor any agency thereof, nor any of their employees, makes any warranty, express or implied, or assumes any legal liability or responsibility for the accuracy, completeness, or usefulness of any information, apparatus, product, or process disclosed, or represents that its use would not infringe privately owned rights. Reference herein to any specific commercial product, process, or service by trade name, trademark, manufacturer, or otherwise does not necessarily constitute or imply its endorsement, recommendation, or favoring by the United States Government or any agency thereof. The views and opinions of authors expressed herein do not necessarily state or reflect those of the United States Government or any agency thereof.

March 1995

Report prepared for the

United States Department of Energy, Office of International Energy Assessments

under Grant No. DE-FG01-90IE-10859 


\section{DISCLAIMER}

Portions of this document may be illegible in electronic image products. Images are produced from the best available original document. 


\section{Contents}

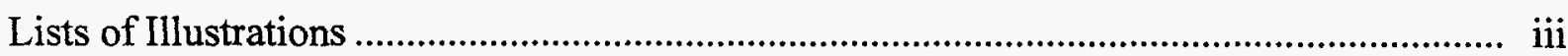

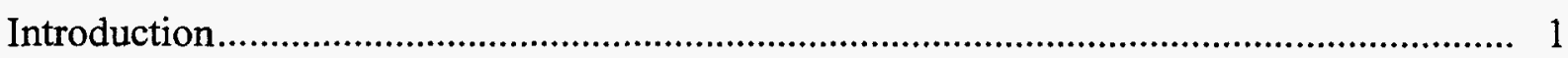

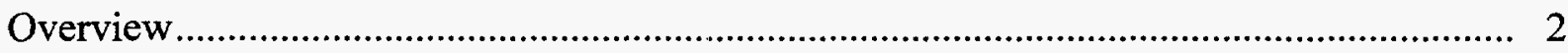

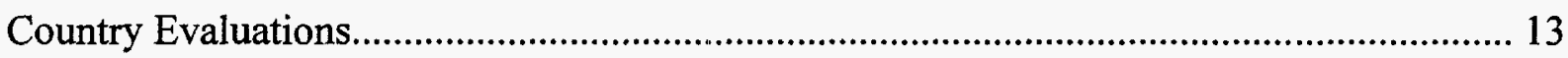

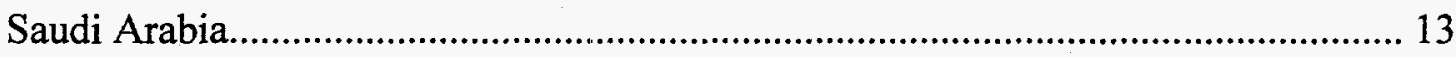

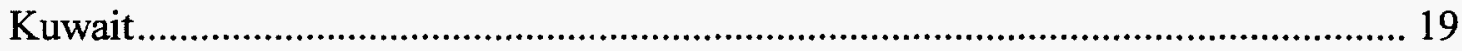

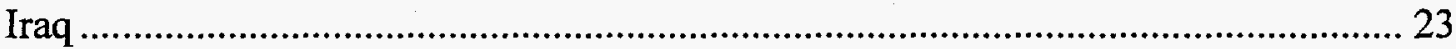

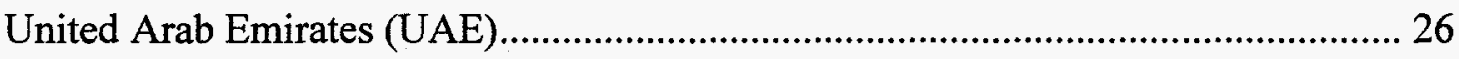

Q

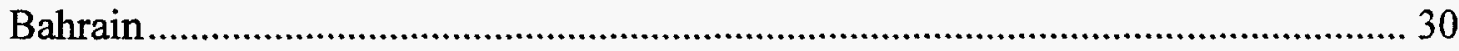

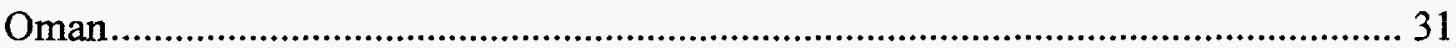

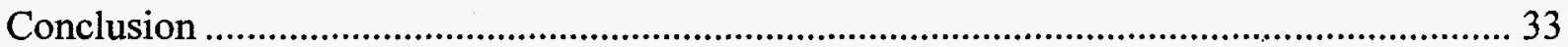

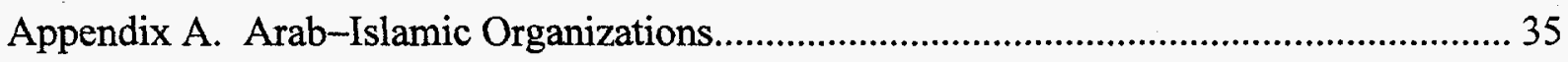




\section{Figure}

1. OPEC Reference Basket Prices: Monthly, 1989, through March 1995

\section{Tables}

1. Economic Indicators for the Persian Gulf Arab Nations

2. The Role of the Persian Gulf Arab Nations 6

3. Crude Oil Production and Quotas, October 1994 - February 1995. 7

4. Production and Reserves for the Persian Gulf Arab Nations 10

5. Current Production, Current Capacity, and Planned Capacity in 2000 11

6. Active Investment Potential. 11

7. Average Formula Prices for Arab Light, May and November 1994

8. Kuwait's 1994 Crude Oil Production, Crude Oil Exports, and Refined Products Exports 


\section{Introduction}

At its heart, Arab oil policy is inseparable from Arab economic and social policy. This holds whether we are talking about the Arab nations as a group or each separately. The seven Arab nations covered in this report-Bahrain, Iraq, Kuwait, Oman, Qatar, Saudi Arabia, and the United Arab Emirates_participate in several organizations ${ }^{1}$ focusing on regional cooperation regarding economic development, social programs, and Islamic unity, as well as organizations concerned with oil policies. This report focuses on the oilrelated activities of the countries that may reveal the de facto oil policies of the seven Persian Gulf nations. Nevertheless it should be kept in mind that the decision makers participating in the oil policy organizations are also involved with the collaborative efforts of these other organizations.

Oil policies of five of the seven Arab nations are expressed within the forums of the Organization of Petroleum Exporting Countries (OPEC) and the Organization of Arab Petroleum Exporting Countries (OAPEC). Only Oman, among the seven, is not a member of either OAPEC or OPEC; Bahrain is a member of OAPEC but not of OPEC. OPEC and OAPEC provide forums for compromise and cooperation among their members. Nevertheless, each member state maintains its own sovereignty and follows its own policies. Each country deviates from the group prescription from time to time, depending upon individual circumstances.

One avenue to assess Gulf Arab oil policies is to evaluate what they are actually doing, in conjunction with what they have said they would be doing. For example, in November 1994, at OPEC's annual meeting held in Jakarta, the decision was made to maintain the existing production quota for all of 1995. This surprised some, who had expected a six-month extension, believing that a six-month extension would be sufficient to stabilize prices. The intent of the quota "rollover" decision was to shore up the image of OPEC with respect to its ability to stay the course on quotas. The expectation was that by demonstrating firmness on the quotas, the world oil market would take OPEC more seriously and prices would stabilize. How well has OPEC in total, and each country individually, done with respect to meeting the quotas?

\footnotetext{
${ }^{1}$ Refer to the appendix of this report for a selected list of organizations focused on Arab economic and social issues. The appendix suggests a high level of involvement in these organizations by the seven nations studied in this report. When viewed with their involvement with OPEC and OAPEC, the interrelationships look somewhat like an example of an elaborate interlocking directorate.
} 
Overproduction has continued to occur and prices have remained soft. (Note that while prices have shown some strength as of early April, the market fundamentals do not support a prolonged price rise.) The seven Gulf Arab states have shown through other oil sector activities that they intend to broaden their investments and participate further in downstream and petrochemical operations, both within their own domestic markets and in foreign markets around the globe. Moreover, they have begun to allow more foreign investment into much, although not all, of their domestic oil sector activities. However, persistent budget deficits and soft oil prices will likely hasten the movement, already under way, toward privatization of domestic industries.

The next section of this report provides general information regarding the economies of the seven nations and specific data with respect to their oil sector activities. This is then followed by a nation-by-nation evaluation of oil sector activities and policies.

\section{Overview}

We first look at the general level of economic activity and the value of exports from each of the countries. Table 1 provides selected economic measures for each of the seven Persian Gulf Arab nations. The GDP data for Iraq covers only the first half of 1990, the period just preceding the Gulf War. We assume that Iraq's budget is in deficit since oil export earnings are severely restricted. ${ }^{2}$ The data for Bahrain and Qatar are for 1993, while the data for the remaining four nations are 1994 estimates. The size of the GDPs for the seven nations is consistent with their volume of crude oil output.

Oil exports constitute a significant share of each nation's exports. The norm is for the value of petroleum-related exports to account for more than 75 percent of the value of total exports. The petroleum-related exports for Kuwait and Saudi Arabia account for 95 percent of the value of their exports. The petroleum-export figure for Saudi Arabia includes the value of petrochemical and plastics exports. The UAE presents an unusual picture regarding the role of oil in its export mix. The reason for the relatively low share, 51 percent, is that Dubai conducts an active reexport business, which reaches into all of the Gulf Arab states plus Iran, who is the dominant trading partner.

\footnotetext{
${ }^{2}$ Iraq is allowed to export relatively small quantities of crude oil to Jordan. These volumes amount to only around 60,000 barrels per day.
} 
Table 1. Economic Indicators for the Persian Gulf Arab Nations

\begin{tabular}{lcccc}
\hline Country and Year & $\begin{array}{c}\text { GDP } \\
\text { (US\$ billion) }\end{array}$ & $\begin{array}{c}\text { Total Exports } \\
\text { (US\$ billion) }\end{array}$ & $\begin{array}{c}\text { Petroleum Exports } \\
\text { (US\$ billion) }\end{array}$ & $\begin{array}{c}\text { Budget } \\
\text { Balance }\end{array}$ \\
\hline Bahrain (1993) & 4.52 & 3.42 & 2.61 & deficit \\
Iraq (Jan.-June 1990) & 35.00 & 14.50 & 14.60 & deficit \\
Kuwait (1994) & 23.50 & 10.54 & 10.00 & deficit \\
Oman (1994) & 11.94 & 4.87 & 4.24 & deficit \\
Qatar (1993) & 7.42 & 3.41 & 2.62 & deficit \\
Saudi Arabia (1994) & 125.71 & 48.22 & 46.11 & deficit \\
UAE (1994) & 36.77 & 23.56 & 12.12 & surplus \\
\hline
\end{tabular}

Source: Country Reports (first quarter 1995), Economist Intelligence Unit.

a. Petroleum exports include petrochemicals and plastics.

The dependency of each nation on oil exports has led to government budgetary problems. With the exception of the UAE, the six remaining nations are all experiencing fiscal deficits. Moreover, the deficits are expected to persist. The value of oil is effectively the only tax base for these countries. A brief look at the value of the OPEC reference basket ${ }^{3}$ will provide a good hint as to the cause of their problems. The reference basket price may be viewed as an indicator of the success of the member country policies. The target reference-basket price is $\$ 21.00$ per barrel, and quotas are established and adjustments are made with a goal of attaining that target.

Figure 1 shows the monthly reference basket prices for the January 1989 through March 1995 period. The average basket price reached $\$ 22.26$ per barrel for 1990; this high average price was the result of the run-up of the price during the Gulf War, when the basket price climbed to $\$ 34.32$ a barrel for October. The basket price declined rapidly from the October high, falling back into the $\$ 17.00$ per barrel range by February 1991 ; in fact, the average basket price for March 1991 was below the annual average basket price for 1989. The average annual reference basket price fell in each year after 1990 until it reached $\$ 15.53$ for 1994. Moreover, the annual average basket prices for 1993 and 1994 were both below that for 1989, in nominal terms. Nevertheless, the first three months of

\footnotetext{
${ }^{3}$ The OPEC reference basket is made up of six of OPEC's crude oils and one Mexican: Saharan Blend (Algeria), Minas (Indonesia), Bonny Light (Nigeria), Arab Light (Saudi Arabia), Dubai (UAE), Tia Juana Light (Venezuela), and Isthmus (Mexico). The reference basket price is the simple average of these seven crude oils.
} 
Figure 1. OPEC Reference Basket Prices: Monthly, 1989 through March 1995 (Nominal)

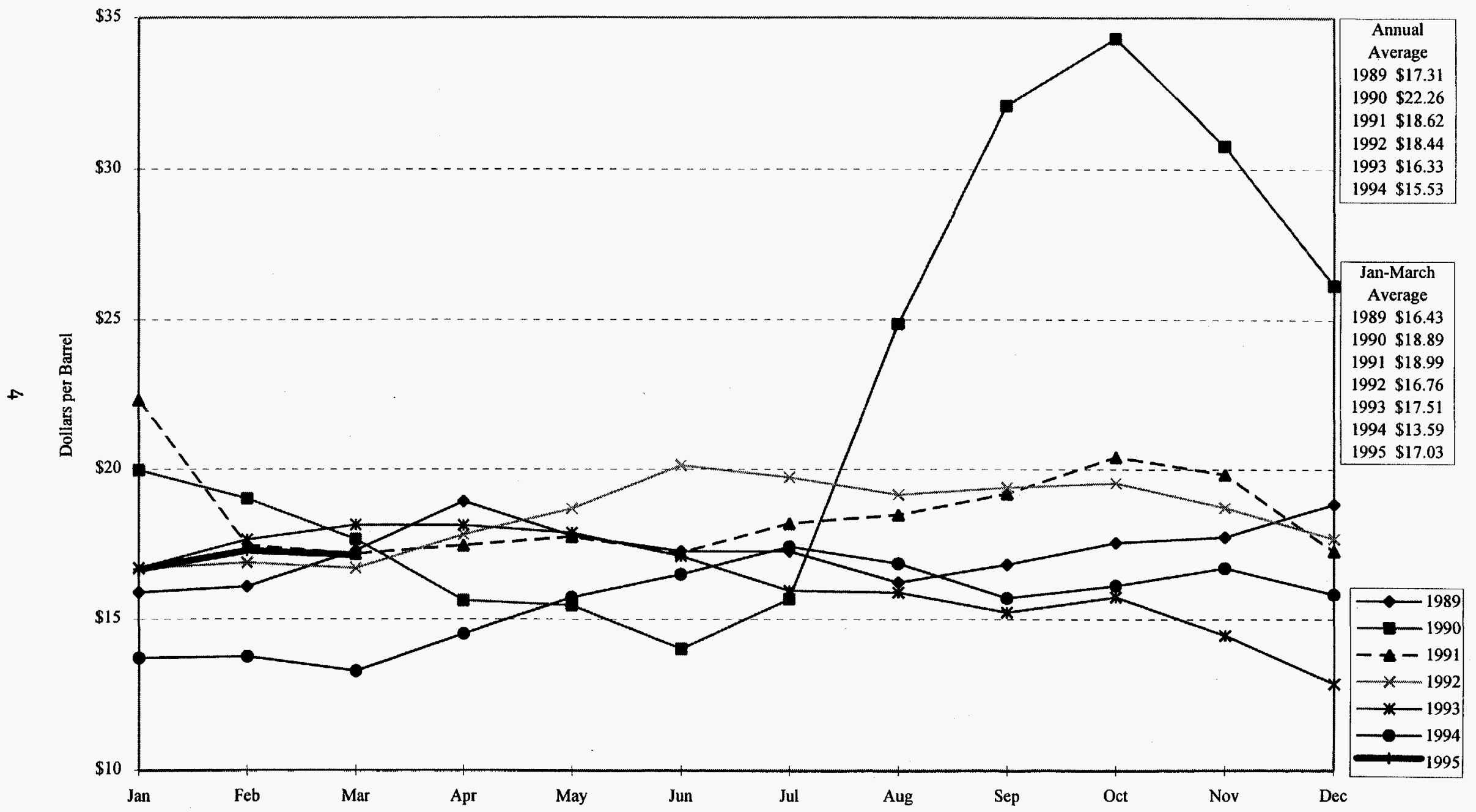

The OPEC Reference Basket includes: Sahara Blend (Algeria), Minas (Indonesia), Bonny Light (Nigeria), Arab Light (Saudi Arabia), Dubai (UAE), Tia Juana Light (Venezuela), and Isthmus (Mexico). Sources: OPEC Annual Statistical Bulletins and Middle East Economic Survey. 
1995 have shown some strength with a pattern similar to, but slightly higher than, that for the same three-month period in 1992.

The seven Gulf Arab states play a significant role in the world oil market. Table 2 shows relationships among the members of OPEC, OAPEC, and the members of the group of Persian Gulf Arab nations (PGAN) that are discussed in this report. Further, the table shows the relationships with the rest of the world. The table emphasizes the concentration of crude oil reserves in the Gulf Arab nations and their likely longevity, even within the organizational structures of OPEC and OAPEC.

The PGAN constitute a significant force in the world oil market and clearly can exercise a significant influence within both OPEC and OAPEC regarding oil policy. The total estimated proved reserves for the Gulf Arab states is 564.5 billion barrels, or 56.5 percent of estimated world crude oil reserves at the beginning of 1995. They account for 73.3 percent of OPEC and 94.5 percent of OAPEC reserves. The "rest of the world," i.e., non-OPEC, non-OAPEC, and non-PGAN, proved reserves were estimated to be 229.5 billion barrels.

The production rates of the Gulf Arab states are relatively low, compared with their share of reserves. The PGAN average daily production was 14,116 barrels per day (b/d) for 1994. This level of production accounted for 23.4 percent of the total world production, 56.6 percent for OPEC, and 83.6 percent for OAPEC. The relatively low production rate for the seven Gulf Arab states implies a long reserves-to-production (R/P) life. Indeed, the R/P ratio for the PGAN is nearly 110 years at the 1994 production rates, while the total world stands at 45 years, OPEC at 85 years, and OAPEC at 96.9 years. The "rest of the world" has an R/P ratio of just 19 years, based on average production of 33,095 thousand $\mathrm{b} / \mathrm{d}$.

The Gulf Arab states are not uniformly endowed with crude oil. Qatar, Oman, and Bahrain have R/P ratios of 24.9, 16.5, and 5.5 years, respectively. Qatar, which has enormous natural gas reserves, and Oman, which claims growing natural gas reserves, are both planning a future around natural gas exports. Bahrain, which is endowed with limited hydrocarbon resources, is developing its manufacturing sector.

Five of the Gulf Arab states are members of OPEC and are subject to the quotas that are established through consensus negotiations. Table 3 reports the OPEC quotas, including the PGAN, and the individual country production rates since October 1994. 
Table 2. The Role of the Persian Gulf Arab Nations (PGAN)

\begin{tabular}{|c|c|c|c|c|c|c|c|c|c|c|c|c|}
\hline \multirow[b]{2}{*}{ Country } & \multicolumn{4}{|c|}{$\begin{array}{l}\text { Estimated Proved Crude Oil Reserves, January 1, } 1995 \\
\text { (thousand barrels) }\end{array}$} & \multicolumn{4}{|c|}{$\begin{array}{l}\text { Estimated Crude Oil Production, } 1994 \\
\text { (thousand barrels/day) }\end{array}$} & \multicolumn{4}{|c|}{$\begin{array}{l}\text { Reserves-to-Production Ratio } \\
\text { (1994 Production Estimate) }\end{array}$} \\
\hline & World & OPEC & OAPEC & PGAN & World & OPEC & OAPEC & PGAN & World & OPEC & OAPEC & PGAN \\
\hline Saudi Arabia & $261,203,000$ & $261,203,000$ & $261,203,000$ & $261,203,000$ & 8011.7 & 8011.7 & 8011.7 & 8011.7 & 89.3 & 89.3 & 89.3 & 89.3 \\
\hline Iraq & $100,000,000$ & $100,000,000$ & $100,000,000$ & $100,000,000$ & 520.0 & 520.0 & 520.0 & 520.0 & 526.9 & 526.9 & 526.9 & 526.9 \\
\hline UAE & $98,100,000$ & $98,100,000$ & $98,100,000$ & $98,100,000$ & 2230.0 & 2230.0 & 2230.0 & 2230.0 & 120.5 & 120.5 & 120.5 & 120.5 \\
\hline Kuwait* & $96,500,000$ & $96,500,000$ & $96,500,000$ & $96,500,000$ & 2038.8 & 2038.8 & 2038.8 & 2038.8 & 129.7 & 129.7 & 129.7 & 129.7 \\
\hline Oman & $4,828,000$ & - & - & $4,828,000$ & 803.8 & - & - & 803.8 & 16.5 & - & - & 16.5 \\
\hline Qatar & $3,700,000$ & $3,700,000$ & $3,700,000$ & $3,700,000$ & 406.7 & 406.7 & 406.7 & 406.7 & 24.9 & 24.9 & 24.9 & 24.9 \\
\hline Bahrain & 210,000 & - & 210,000 & 210,000 & 105.3 & - & 105.3 & 105.3 & 5.5 & - & 5.5 & 5.5 \\
\hline Egypt & $3,260,000$ & - & $3,260,000$ & - & 893.3 & - & 893.3 & - & 10.0 & - & 10.0 & - \\
\hline Syria & $2,500,000$ & - & $2,500,000$ & - & 570.0 & - & 570.0 & - & 12.0 & - & 12.0 & . \\
\hline Iran & $89,250,000$ & $89,250,000$ & - & - & 3572.5 & 3572.5 & - & - & 68.4 & 68.4 & - & . \\
\hline Venezuela & $64,477,000$ & $64,477,000$ & - & - & 2463.3 & 2463.3 & - & - & 71.7 & 71.7 & - & - \\
\hline Libya & $22,800,000$ & $22,800,000$ & $22,800,000$ & - & 1367.5 & 1367.5 & 1367.5 & - & 45.7 & 45.7 & 45.7 & $=$ \\
\hline Nigeria & $17,899,820$ & $17,899,820$ & - & - & 1930.0 & 1930.0 & - & - & 25.4 & 25.4 & - & . \\
\hline Algeria & $9,200,000$ & $9,200,000$ & $9,200,000$ & - & 745.0 & 745.0 & 745.0 & - & 33.8 & 33.8 & 33.8 & - \\
\hline Indonesia & $5,779,000$ & $5,779,000$ & - & - & 1328.7 & 1328.7 & - & - & 11.9 & 11.9 & - & . \\
\hline Gabon ** & $1,340,000$ & $1,340,000$ & - & - & 329.2 & 329.2 & - & - & 11.2 & 11.2 & - & . \\
\hline \multicolumn{13}{|l|}{ Rest of } \\
\hline World & $229,512,017$ & - & - & - & 33095.9 & - & - & - & 19.0 & - & - & - \\
\hline World Total & $999,760,837$ & $770,248,820$ & $597,473,000$ & $564,541,000$ & 60411.6 & 24943.3 & 16888.2 & 14116.2 & 45.3 & 84.6 & 96.9 & 109.6 \\
\hline \multicolumn{13}{|l|}{$\begin{array}{l}\text { Totals as a } \\
\% \text { of }\end{array}$} \\
\hline World & $100.0 \%$ & $77.0 \%$ & $59.8 \%$ & $56.5 \%$ & $100.0 \%$ & $41.3 \%$ & $28.0 \%$ & $23.4 \%$ & $100.0 \%$ & $186.6 \%$ & $213.8 \%$ & $241.7 \%$ \\
\hline OPEC & & $100.0 \%$ & $77.6 \%$ & $73.3 \%$ & & $100.0 \%$ & $67.7 \%$ & $56.6 \%$ & & $100.0 \%$ & $114.6 \%$ & $129.5 \%$ \\
\hline OPAEC & & & $100.0 \%$ & $94.5 \%$ & & & $100.0 \%$ & $83.6 \%$ & & & $100.0 \%$ & $113.0 \%$ \\
\hline PGAN & & & & $100.0 \%$ & & & & $100.0 \%$ & & & & $100.0 \%$ \\
\hline
\end{tabular}

Source: Oil \& Gas Journal, December 26, 1994

* The Neutral Zone reserves and production are equally split between Saudi Arabia and Kuwait.

** Gabon has given notice that it will be leaving OPEC 
Table 3. OPEC Crude Oil Production and Quotas, October 1994-February 1995 (thousand barrels per day)

\begin{tabular}{|c|c|c|c|c|c|c|c|c|c|c|c|c|c|}
\hline \multirow[b]{2}{*}{ Country } & \multicolumn{9}{|c|}{1994} & \multicolumn{4}{|c|}{1995} \\
\hline & $\begin{array}{l}\text { OPEC } \\
\text { Quota } \\
\end{array}$ & \multicolumn{2}{|r|}{$\begin{array}{r}\% \text { over } \\
\text { quota } \\
\end{array}$} & November & \multicolumn{2}{|c|}{$\begin{array}{l}\% \text { over } \\
\text { quota December }\end{array}$} & \multirow{2}{*}{$\begin{array}{r}\% \text { over } \\
\text { quota } \\
0.0 \%\end{array}$} & \multirow{2}{*}{$\frac{\text { Year }}{748}$} & \multirow{2}{*}{$\begin{array}{r}\begin{array}{r}\% \text { over } \\
\text { quota }\end{array} \\
-0.3 \%\end{array}$} & \multirow{2}{*}{$\frac{\text { January }}{750}$} & \multirow{2}{*}{$\begin{array}{r}\% \text { over } \\
\text { quota } \\
0.0 \%\end{array}$} & \multirow{2}{*}{$\frac{\text { February }}{750}$} & \multirow{2}{*}{$\begin{array}{r}\% \text { over } \\
\text { quota } \\
0.0 \%\end{array}$} \\
\hline Algeria & 750 & 750 & $0.0 \%$ & 750 & $0.0 \%$ & 750 & & & & & & & \\
\hline Gabon & 287 & 340 & $18.5 \%$ & 340 & $18.5 \%$ & 340 & $18.5 \%$ & 324 & $12.9 \%$ & 340 & $18.5 \%$ & 340 & $18.5 \%$ \\
\hline Indonesia & 1,330 & 1,350 & $1.5 \%$ & 1,340 & $0.8 \%$ & 1,330 & $0.0 \%$ & 1,321 & $-0.7 \%$ & 1,350 & $1.5 \%$ & 1,330 & $0.0 \%$ \\
\hline Iran & 3,600 & 3,490 & $-3.1 \%$ & 3,700 & $2.8 \%$ & 3,685 & $2.4 \%$ & 3,583 & $-0.5 \%$ & 3,530 & $-1.9 \%$ & 3,770 & $4.7 \%$ \\
\hline Iraq & 400 & 500 & $25.0 \%$ & 540 & $35.0 \%$ & 540 & $35.0 \%$ & 506 & $26.5 \%$ & 540 & $35.0 \%$ & 540 & $35.0 \%$ \\
\hline Kuwait & 2,000 & 2,000 & $0.0 \%$ & 2,000 & $0.0 \%$ & 2,000 & $0.0 \%$ & 2,000 & $0.0 \%$ & 2,000 & $0.0 \%$ & 2,000 & $0.0 \%$ \\
\hline Libya & 1,390 & 1,380 & $-0.7 \%$ & 1,400 & $0.7 \%$ & 1,400 & $0.7 \%$ & 1,392 & $0.1 \%$ & 1,400 & $0.7 \%$ & 1,400 & $0.7 \%$ \\
\hline Nigeria & 1,865 & 1,920 & $2.9 \%$ & 1,860 & $-0.3 \%$ & 1,900 & $1.9 \%$ & 1,877 & $0.6 \%$ & 1,860 & $-0.3 \%$ & 1,850 & $-0.8 \%$ \\
\hline Qatar & 378 & 360 & $-4.8 \%$ & 400 & $5.8 \%$ & 400 & $5.8 \%$ & 399 & $5.6 \%$ & 420 & $11.1 \%$ & 420 & $11.1 \%$ \\
\hline S. Arabia & 8,000 & 8,000 & $0.0 \%$ & 8,000 & $0.0 \%$ & 8,000 & $0.0 \%$ & 8,000 & $0.0 \%$ & 8,000 & $0.0 \%$ & 8,000 & $0.0 \%$ \\
\hline UAE & 2,161 & 2,160 & $0.0 \%$ & 2,180 & $0.9 \%$ & 2,195 & $1.6 \%$ & 2,180 & $0.9 \%$ & 2,200 & $1.8 \%$ & 2,200 & $1.8 \%$ \\
\hline Venezuela & 2,359 & 2,500 & $6.0 \%$ & 2,450 & $3.9 \%$ & 2,450 & $3.9 \%$ & 2,456 & $4.1 \%$ & 2,500 & $6.0 \%$ & 2,500 & $6.0 \%$ \\
\hline Total OPEC & 24,520 & 24,750 & $0.9 \%$ & 24,960 & $1.8 \%$ & 24,990 & $1.9 \%$ & 24,786 & $1.1 \%$ & 24,890 & $1.5 \%$ & 25,100 & $2.4 \%$ \\
\hline Total PGAN & 12,939 & 13,020 & $0.6 \%$ & 13,120 & $1.4 \%$ & 13,135 & $1.5 \%$ & 13,085 & $1.1 \%$ & 13,160 & $1.7 \%$ & 13,160 & $1.7 \%$ \\
\hline \multicolumn{14}{|l|}{ PGAN Share } \\
\hline of OPEC Total & $52.8 \%$ & $52.6 \%$ & & $52.6 \%$ & & $52.6 \%$ & & $52.8 \%$ & & $52.9 \%$ & & $52.4 \%$ & \\
\hline
\end{tabular}

Source: Middle East Economic Survey. 
The five Gulf Arab nations account for 52.8 percent of the total OPEC quota, and they accounted for roughly the same percentage of the estimated production. The table indicates that "cheating" has occurred in each month of the five months shown, as well as on average for all of 1994. The five OPEC-member Gulf Arab nations-Iraq, Kuwait, Qatar, Saudi Arabia, and the UAE - are net cheaters if regarded as a single unit. However, since Kuwait and Saudi Arabia are reported to have held the line on their quotas, the overproduction is the result of production decisions by Iraq, Qatar, and the UAE.

With the exception of January 1995, the percentage of overproduction by the five PGAN OPEC members was less than that for OPEC as a whole. However, this figure is somewhat misleading. When Kuwait and Saudi Arabia are dropped from the calculation, it is clear that the bulk of the overproduction originates in the Arab Gulf. Viewed in this manner, while the non-Kuwait/Saudi OPEC overproduction ranged between 1.6 and 4.0 percent, the non-Kuwait/Saudi Gulf Arab states' overproduction ranged between 2.8 and 7.5 percent.

The single largest "overproducer" has been Iraq. Iraq has never accepted the $400,000 \mathrm{~b} / \mathrm{d}$ quota, arguing that it should be governed by the July 1990 quota of 3.14 million ( $\mathrm{mn}$ ) $\mathrm{b} / \mathrm{d}$, the last in which Iraq played a full market role in the OPEC negotiations. Iraq exceeded its quota by 25 percent in October 1994, and by 35 percent in each month since. The real effect of Iraq's overproduction is difficult to determine, because it is not clear just how much of the production is entering the international market.

The only other persistently significant overproducer in percentage terms from our group of five is Qatar, overproducing by $42,000 \mathrm{~b} / \mathrm{d}$, or 11.1 percent of its quota. However, the 1.8 percent overproduction for the UAE is roughly equivalent in terms of barrels, at $39,000 \mathrm{~b} / \mathrm{d}$ for January and February 1995. These three Gulf Arab members of OPEC were responsible for 38 percent of the $580,000 \mathrm{~b} / \mathrm{d}$ overproduction for February 1995. These three countries produced an excess of $221,000 \mathrm{~b} / \mathrm{d}$, of which Iraq was responsible for $140,000 \mathrm{~b} / \mathrm{d}$. That is, Iraq was responsible for 63 percent of the Gulf Arab states' overproduction and for 24 percent of all of OPEC's overproduction. The OPEC average rate of overproduction for all of 1994 was $266,000 \mathrm{~b} / \mathrm{d}$. The three PGAN OPEC members accounted for $146,000 \mathrm{~b} / \mathrm{d}$, or 55 percent, and Iraq alone accounted for 106,000 $\mathrm{b} / \mathrm{d}$, or 73 percent of the Gulf Arab states' overproduction and 40 percent of that for total OPEC. 
Table 4 reports estimated proved reserves of crude oil and natural gas for the seven nations, with the UAE's total broken out for four of its oil and gas bearing emirates. The first thing that one notices is the large volume of proved reserves held by the seven nations—over 56 percent of world's claimed crude oil reserves and over 16 percent of natural gas. Iraq's impressive 527-year reserves-to-production ratio is reduced to a still considerable 91 years, if its 1994 production is replaced in the equation with the $3 \mathrm{mn} \mathrm{b} / \mathrm{d}$ it could easily produce. If Iraq's desired $3 \mathrm{mn} \mathrm{b} / \mathrm{d}$ is also factored into the $\mathrm{R} / \mathrm{P}$ ratio for the group of seven, the group R/P ratio drops from 110 to 93 years, if no one offsets the increase, which is still impressive. The other $\mathrm{R} / \mathrm{P}$ ratios mentioned earlier would also decrease: to 43.6, 77.0, and 84.5 years for the total world, OPEC, and OAPEC, respectively.

The claimed natural gas reserves are large and growing. The reserve estimates are taken from the Oil and Gas Journal, December 26, 1994. Since these estimates were published, the Minister of Petroleum and Minerals of Oman has reported that Oman's "bankable" natural gas reserves are now at 24 trillion cubic feet (tcf), up from the 22 tcf reported in our table. The single largest concentration of natural gas in the PGAN is found in Qatar, with 250 tcf, followed by the UAE, with 205 tcf (92 percent of this is located in Abu Dhabi). With the exception of Bahrain, all of the nations have R/P ratios of over 140 years, at 1993 production rates. This suggests that even after the several export projects come on line, the life of these reserves will still tend to exceed 100 years.

Table 5 reports the current rate of crude oil production by the seven Gulf Arab nations, as well as their current production capacity and their expected production capacity in the year 2000. Total production for the Gulf Arab states was nearly $14 \mathrm{mn} b / \mathrm{d}$ for March 1995, which was roughly 73 percent of the current production capacity of just over $19 \mathrm{mn} \mathrm{b} / \mathrm{d}$. Between now and the turn of the century, production capacity for the group is expected to increase by about 12 percent. The percentage increase in production capacity varies across the seven nations, ranging from Bahrain remaining flat at 40,000 $\mathrm{b} / \mathrm{d}$ to Iraq increasing by nearly 35 percent from its current $2.6 \mathrm{mn} \mathrm{b} / \mathrm{d}$ capacity to $3.5 \mathrm{mn}$ $\mathrm{b} / \mathrm{d}$ by 2000 . Kuwait is also expected to register a significant increase in capacity, growing by 25 percent from the current $2.4 \mathrm{mn} \mathrm{b} / \mathrm{d}$ to $3.0 \mathrm{mn} \mathrm{b} / \mathrm{d}$. It should be noted that while the overall production capacity for the UAE is expected to increase by over 8.5 percent, Dubai's capacity will decline from its current level of $350,000 \mathrm{~b} / \mathrm{d}$ to around $150,000 \mathrm{~b} / \mathrm{d}$ in 2000 . The capacity gain for UAE is the result of expansions in Abu Dhabi. 
Table 4. Production and Reserves for the Persian Gulf Arab Nations

\begin{tabular}{|c|c|c|c|c|c|c|c|}
\hline \multirow[b]{2}{*}{ Country } & \multicolumn{2}{|c|}{$\begin{array}{c}\text { Estimated Proved Reserves } \\
\text { (January 1, 1995) }\end{array}$} & \multicolumn{3}{|c|}{$\begin{array}{l}\text { Crude Oil } \\
\text { Production }\end{array}$} & \multicolumn{2}{|l|}{$\begin{array}{c}\text { Natural Gas } \\
\text { Production }\end{array}$} \\
\hline & $\begin{array}{r}\text { Natural Gas } \\
\text { (billion cubic feet) }\end{array}$ & $\begin{array}{r}\text { Crude Oil } \\
\text { (thousand barrels) }\end{array}$ & $\begin{array}{r}\text { Actual } 1993 \\
\text { (thousand } \\
\text { barrels/day) }\end{array}$ & $\begin{array}{r}\text { Est. } 1994 \\
\text { (thousand } \\
\text { barrels/day) }\end{array}$ & $\begin{array}{r}1994 \mathrm{R} / \mathrm{P} \\
\text { Ratio (years) }\end{array}$ & $\begin{array}{r}1993 \\
\text { (billion cubic feet) }\end{array}$ & $\begin{array}{r}1993 \mathrm{R} / \mathrm{P} \\
\text { Ratio (years) }\end{array}$ \\
\hline Bahrain & 5,295 & 210,000 & 106.0 & 105.3 & 5.5 & 271.7 & 19.5 \\
\hline Iraq & 109,500 & $100,000,000$ & 447.5 & 520.0 & 526.9 & 91.7 & $1,194.1$ \\
\hline Kuwait * & 52,900 & $96,500,000$ & $1,870.0$ & $2,038.8$ & 129.7 & 158.8 & 333.1 \\
\hline Oman & 22,248 & $4,828,000$ & 779.1 & 803.8 & 16.5 & 98.1 & 226.8 \\
\hline Qatar & 250,000 & $3,700,000$ & 429.2 & 406.7 & 24.9 & 476.3 & 524.9 \\
\hline Saudi Arabia * & 185,900 & $261,203,000$ & $8,087.1$ & $8,011.7$ & 89.3 & $1,266.7$ & 146.8 \\
\hline UAE & 204,600 & $98,100,000$ & $2,195.0$ & $2,230.0$ & 120.5 & 882.1 & 231.9 \\
\hline - Abu Dhabi & 188,400 & $92,200,000$ & $1,800.0$ & $1,840.0$ & 137.3 & & \\
\hline - Dubai & 4,400 & $4,300,000$ & 350.0 & 340.0 & 34.6 & & \\
\hline - Ras Al-Khaimah & 1,100 & 100,000 & 1.0 & 1.0 & 274.0 & & \\
\hline - Sharjah & 10,700 & $1,500,000$ & 44.0 & 49.0 & 83.9 & & \\
\hline Total PGAN & 830,443 & $564,541,000$ & $13,913.9$ & $14,116.2$ & 109.6 & $3,245.4$ & 255.9 \\
\hline World Total & $4,980,278$ & $999,760,837$ & $59,780.8$ & $60,411.6$ & 45.3 & $73,927.8$ & 67.4 \\
\hline $\begin{array}{l}\text { PGAN Share of } \\
\text { World Total }\end{array}$ & $16.7 \%$ & $56.5 \%$ & $23.3 \%$ & $23.4 \%$ & & $4.4 \%$ & \\
\hline
\end{tabular}

Source: Oil and Gas Journal, for oil and gas reserves and oil production; BP Review of World Gas 1994, for gas production.

* Neutral Zone divided equally between Kuwait and Saudi Arabia.

Note: Table 4 production is simple wellhead production. Table 3 production data represent the supply definition report to and by OPEC. 
Table 5. Current Production, Current Capacity, and Planned Capacity in 2000 (thousand barrels per day)

\begin{tabular}{lrrrc}
\hline Country & $\begin{array}{c}\text { Current } \\
\text { Production }^{\mathrm{a}}\end{array}$ & $\begin{array}{c}\text { Current } \\
\text { Capacity }\end{array}$ & $\begin{array}{c}\text { Planned 2000 } \\
\text { Capacity }\end{array}$ & $\begin{array}{c}\text { Capacity } \\
\text { Increase (\%) }\end{array}$ \\
\hline Bahrain $^{\mathrm{b}}$ & 40 & 40 & 40 & 0.00 \\
Iraq & 540 & 2,600 & 3,500 & 34.62 \\
Kuwait & 2,000 & 2,400 & 3,000 & 25.00 \\
Oman & 830 & 850 & 900 & 5.88 \\
Qatar & 410 & 420 & 450 & 7.14 \\
Saudi Arabia & 8,000 & 10,000 & 10,500 & 5.00 \\
UAE & 2,174 & 2,900 & 3,150 & 8.62 \\
Total & 13,994 & 19,210 & 21,540 & 12.13 \\
\hline Capacity Utilization & & $72.8 \%$ & & \\
\hline
\end{tabular}

a. March 1995 production levels; "supply" volumes for the five OPEC members.

b. Production from Bahraini domestic fields; excludes volumes allocated by Saudi Arabia.

c. Dubai is currently producing $350,000 \mathrm{~b} / \mathrm{d}$, but production is expected to decline to $150,000 \mathrm{~b} / \mathrm{d}$ by 2000 .

The remainder of the UAE production capacity will exist primarily in Abu Dhabi.

Table 6. Active Investment Potential

\begin{tabular}{lccccccc}
\hline Sector & Iraq & Kuwait & Saudi Arabia & UAE & Bahrain & Qatar & Oman \\
\hline Upstream Oil & yes & yes & no & yes & yes & yes & yes \\
Refining & no & no & export & no & yes & no & yes \\
Oil Marketing & no & no & lubes & yes & no & no & yes \\
Domestic & yes & yes? & no & yes & yes & yes & yes \\
Upstream Gas & & & & & & & \\
LNG & no & no & no & yes & - b & yes & yes \\
Electricity & no & no & possibly & no & yes & no & yes \\
Petrochemicals & no & yes & yes & yes & yes & yes & yes \\
\hline
\end{tabular}

a. There are indications that private foreign investment might be permitted at Shaybah.

b. Not applicable. 
Investment opportunities within these nations have been presented in a recent EWC/PREM report, which arrived at the following summary conclusions (Table 6) regarding the likelihood of available opportunities for foreign investors, by subsector of the energy industry. ${ }^{4}$

The investment opportunities for foreigners are a mixed bag, but the area is clearly not unfriendly to outside investment.

However, a point or two on the possible interplay between the foreign investment policies and other oil policies is worth noting. With the exception of Saudi Arabia, foreign opportunities in upstream production operations are available. In some cases these commercial opportunities link the returns of the foreign company to the rate of production, while others are fee-based contracts without entitlements to crude oil production. Current and possible future expansion of joint-venture investments in upstream production facilities may lead to heightened tensions among the Arab nations - and with other OPEC members - and between the nations and their foreign investment partners. Private investors enter into joint ventures, just like any other investment, with an expected rate of return in mind. There is typically a minimum or hurdle rate that they must expect to be the likely outcome before they will commit to an investment.

When actual rates fall below those that were expected, private investors will try to find ways to bring the actual returns back into line with expectations. When revenues fall off, as they have with both lower prices and production restrictions, there will be pressure from the private investors to increase revenues. One avenue to increased revenues is increased output. Pressure has already been felt in Abu Dhabi, among others, and Abu Dhabi's production has exceeded quota limits, when added to Dubai production. It is difficult to determine the degree of causality between private investor pressure and overproduction, but the pressure will remain. Abu Dhabi has noted that it would like to produce closer to its claimed capacity of $2.6 \mathrm{mn}$ barrels per day (b/d), which significantly exceeds the OPEC quota of $2.16 \mathrm{mn}$ b/d that covers all of the UAE. If world crude oil markets don't tighten soon, leading to stronger prices, the pressures to produce beyond the current quotas can be expected to increase. And given the state of government budgets, some of the pressures may originate from within.

\footnotetext{
4 "Investment Opportunities in the Persian Gulf Energy Sector," by Ronald E. Hagen, Energy Investment Advisory Series, No. 3, January 1995.
} 
Investment outside of the region by the Arab nations may also eventually put upward pressure on the rate of production. Several of the Gulf Arab nations are investing in downstream refinery operations in other countries. Having made those investments, there will be an expectation of return on those investments, which will require that the refineries have sufficient crude oil feedstocks to operate. Feedstock policies and agreements may be quite complex, so the degree of linkage between the foreign downstream investments and the eventual demands on upstream production cannot be unambiguously identified. Nevertheless, there will likely be pressure to produce as a result of these investments.

We next turn to the nation-by-nation evaluation of oil sector activities and policies.

\section{Country Evaluations}

This section examines each of the seven nations separately. It begins with Saudi Arabia, followed by Kuwait, Iraq, the UAE, and Qatar-the five OPEC members. These are followed by Bahrain-a member of OAPEC - and the section closes with the "independent" Oman.

\section{Saudi Arabia}

Saudi Arabia is producing its crude oil within the OPEC established quota rate of 8 million b/d. Saudi reserves, shown in Table 4, amount to 261 billion barrels of oil and almost 186 trillion cubic feet of gas. At 1994 quota-constrained production levels, the reserves-to-production ratio for crude oil is 89 years, and at 1993 productions the R/P ratio for gas is 147 years. Saudi Arabia currently has a production capacity of at least 10 $\mathrm{mn} \mathrm{b} / \mathrm{d}$ for crude oil, and planned development work at the Shaybah field may add a further $500,000 \mathrm{~b} / \mathrm{d}$ of production capacity by 1999 . The output from the Shaybah field, when and if it is brought into production, will be light, low sulfur crude oil- $-41^{\circ}$ API and 0.5 percent sulfur. 
Domestic policy toward oil products has seen a change toward market-related pricing; the prices are still imposed, but they are nearer world levels. The new premium gasoline price is equivalent to around $\$ 0.53$ per U.S. gallon, which puts it on par with wholesale prices on the U.S. Gulf Coast. Jet fuel prices are now also more or less in line with world levels. The retail price of gasoline still falls far below the pump price in most of the developing world. This is the result of very different taxation policies. The price of diesel fuel, at $\$ 0.34$ per gallon wholesale, is low relative to international prices, but for the first time ever the diesel fuel price is above that for heavy fuel oil.

Given the relatively small size of the Saudi petroleum products market, priceinduced consumption reduction will have little effect on the supply-demand balance on a global scale. Domestic consumption amounts to no more than $1.0 \mathrm{mn} \mathrm{b} / \mathrm{d}$. There is concern that the pricing measures will not reduce demand, or its rate of growth, sufficiently to forestall the need to import products. Nevertheless, the domestic policy change, in conjunction with increases in electricity, water, telephone, and visa and work permit fees, is moving in the right direction, although these actions alone will not be sufficient to extract the Saudi government from its existing budget deficit problem.

While concern has been raised regarding the pending product supply deficit, this condition pertains only to the relationship between domestic demand and supplies from the four wholly owned domestic refineries plus 50 percent of the output of the three jointventure refineries. If the remainder of the joint-venture volumes is counted, the incountry volumes are more than enough to satisfy domestic consumption for all products.

One noted failure in the otherwise positive movement toward market-related prices is found with the pricing of crude oil burned directly, i.e., used as boiler fuel, by utilities and heavy industry. The Ministry of Finance and National Economy failed to approve a 239 percent price hike to be applied to direct-burn crude oils. The price for the crude oil will remain at $\$ 4.24$ per barrel, rather than rising to the proposed $\$ 14.40$ per barrel. These industries are able to acquire Arab Light crude oil at prices below world market prices. The proposed price hike would have provided economic incentives for industry to switch to lower-priced heavy fuel oil, or even possibly natural gas.

It might be argued that this distorted pricing scheme makes sense from a Saudi domestic perspective. The primary users of crude oil for direct burning are state-owned utilities, which currently provide subsidized electricity and water. If the utilities had been required to pay the higher price for crude oil or the heavy fuel oil substitute, the 
government would most likely have incurred an offsetting increase in the subsidies provided. Thus, budgetarily the price increase would have meant little. Besides, the two public utilities have not paid their fuel bills since the Gulf War.

Oil policies are affected by domestic concerns. The recent budget deficits in Saudi Arabia, and elsewhere in the Arab oil producing world, are typically blamed on the price of oil in the world market. It is claimed that the price is too low. The "low" price leads to domestic fiscal deficits, which tends to drive oil policy in the direction of supporting or increasing the world price for crude oil. This is due to the fact that roughly 90 percent of the Saudi budget is oil based, with virtually no taxes on Saudis.

However, one could conclude, alternatively, that domestic government spending may simply be too high. The price of oil is not too low to cover the costs associated with finding, extracting, and marketing this resource in the Arab nations, or even for most of the world. After all, that is why the world is experiencing an oil surplus, which is resulting in soft prices. It can only be argued that the price is too low if one artificially incorporates the costs of domestic or regional programs, unrelated to oil production, into the "cost" of finding, extracting, and marketing the crude oil.

The Saudis, and the other Gulf Arab states, have imbedded many price subsidy schemes into their domestic economies, which exacerbate the problems faced when prices weaken. Nevertheless, the existence of such subsidies does not make the world price of oil too low. Rather it signals that in a world market where the price is set by market forces rather than by fiat, domestic pricing policies must also reflect world supply and demand conditions or risk being thrown out of control.

Saudi Arabia's OPEC quota is $8 \mathrm{mn} \mathrm{b} / \mathrm{d}$, and is expected to hold at that level through 1995. OPEC quotas are based on the following definition of supply: domestic consumption, plus net export sales of crude oil and refined products, plus withdrawals from stocks held outside national boundaries. The differences between this definition of supply and a simple wellhead production measurement explains the difference between "production" levels reported in Tables 3 and 4. Table 3 represents the supply definition reported to and by OPEC, while Table 4 is simple wellhead production.

Saudi Aramco, the state-owned oil company, is carrying out a new production policy, and a portion of the change is due to the combination of lower prices, tighter quotas, and growing public sector deficits. The production policy, set by the Ministry of 
Petroleum and Minerals, is to emphasize light crude oil over the heavier crude oils. It is believed that the target is for a ratio of 80 percent light crude oils to 20 percent heavier. The light crude oil volumes will be made up of Arab Light, Extra Light (Berri), and the new Arab Super Light (ASL). The new ASL will compete with the likes of Abu Dhabi's $39^{\circ}$ API Murban. The heavier crude oils are Arab Medium and Arab Heavy. A decade ago, the production-mix policy called for relative balance across all grades.

The current ratio is hovering around 78 percent light, or about $6.2 \mathrm{mn} \mathrm{b} / \mathrm{d}$, of which $5.1 \mathrm{mn} b / \mathrm{d}$ is Arab Light. The remaining $1.1 \mathrm{mn} \mathrm{b} / \mathrm{d}$ would be split between Berri and ASL. However, recent plans to reduce Arab Heavy production to $700,000 \mathrm{~b} / \mathrm{d}$ from $900,000 \mathrm{~b} / \mathrm{d}$ for 1995 , with the difference being made up with light crude oils, would result in 79.5 percent of the production being light, i.e., 79.5 percent of the $8 \mathrm{mn} \mathrm{b} / \mathrm{d}$ quota. ASL's share of this production level is still somewhat of a question mark. Initially, ASL began production in September 1994 at a rate of $170,000 \mathrm{~b} / \mathrm{d}$, from the Hawtah field, located in Central Arabia. By March 1995, the systematic debottlenecking led to production at $200,000 \mathrm{~b} / \mathrm{d}$, which was the target for sustained production. The previously mentioned Shaybah field could add to light crude oil production capacity by the end of the decade.

The change in production policy is largely a result of the Saudi government trying to maximize revenues given the quota constraint. Changes in the structure of prices are favoring the lighter Saudi crude oils, at the expense of the medium and heavy. For example, recently the prices for Saudi crude oil into the U.S. market were increased relative to the West Texas Intermediate (WTI) reference crude oil. The prices for Arab Heavy and Arab Medium were raised by $\$ 0.75$ per barrel (bbl) and $\$ 0.65$ per bbl, respectively, while the price hikes for Arab Light and Extra Light Berri were $\$ 0.50$ and $\$ 0.30$ per bbl, respectively. The pricing relationship shift may reflect world market pressures resulting from existing supply/demand balances of the different crude oil grades, rather than being the result of a deliberate Saudi pricing policy. The relative pricing scheme is also in line with plans to increase the role of light crude oils in the production mix, with a goal of maximizing revenues even while faced with lower prices and a quota.

Saudi Arabian exports are being drawn into the Asia-Pacific market by advantageous pricing differentials, vis-à-vis the traditional markets in Europe and North America. Term pricing of Saudi Arabian crude oils is set by formulas varying with the market targeted. For example, the f.o.b. term-contract formula price for Arab Light 
destined for Europe is based on the price of Brent forty days after the loading of the crude oil in Saudi Arabia, and an adjustment factor. The forty days accounts for the sailing time between Saudi and European port. The adjustment factor accounts for such things as transportation costs and crude oil quality differentials. For the European bound Arab Light, the adjustment factor was a minus $\$ 1.15$ for January 1995 , compared with a minus $\$ 1.45$ for both November and December 1994.

A different pricing formula applies for Arab Light (and other Saudi crude oils, too) destined for the United States and another for the Far East. The U.S. formula uses WTI as the reference, and the Far East formula uses the average of the Oman and Dubai spot prices. No timing adjustment is made for the Far East, while the U.S. price is determined by the price of WTI fifty days following loading. An example of the differences that can result may be seen by observing the May and November 1994 average formula prices for Arab Light into these three markets (Table 7).

While there have been fluctuations in these relationships over time (represented by the relationship shown for May), over the past year the Far East has generally provided Saudi Arabia with a premium over Europe and the United States (represented by November). This pricing relationship has led to a shift in the flow of Saudi exports such that the 1993 share of exports going to the Far East was 44 percent compared with 32.5 percent in 1988. The single largest customer for ASL has been the Ssangyong refinery in South Korea, of which Saudi Aramco owns 35 percent. Given the addition of 200,000 $\mathrm{b} / \mathrm{d}$ of capacity, it can be expected that more light crude oils will flow east.

Table 7. Average Formula Prices for Arab Light, May and November 1994

\begin{tabular}{lcc}
\hline Market & May 1994 & November 1994 \\
\hline Arab Light (Europe) & $\$ 15.80$ & $\$ 14.41$ \\
Arab Light (United States) & $\$ 16.72$ & $\$ 14.73$ \\
Arab Light (Far East) & $\$ 15.29$ & $\$ 16.70$ \\
\hline
\end{tabular}

Source: Petroleum Intelligence Weekly, January 30, 1995. 
Saudi Aramco ownership of foreign oil related assets, like the Ssangyong refinery, is another aspect of Saudi Arabian oil policy that we must look at. In December 1993, Saudi Arabia obtained a 40 percent share in the Philippine refining company Petron, which has a $147,250 \mathrm{~b} / \mathrm{d}$ refinery and a network of over 850 service stations. Saudi Aramco also has equity ownership of over $300,000 \mathrm{~b} / \mathrm{d}$ of refining capacity in the United States through Star Enterprises, a joint venture with Texaco, Inc. China News Digest reported in March 1995 that Saudi Aramco was negotiating with China for participation in a refinery in Southern China: Maoming. The refinery is estimated to cost $\$ 1.5$ billion, with a proposed processing capacity of approximately $100,000 \mathrm{~b} / \mathrm{d}$. It is to go on stream by 1998. Currently, China imports 3.5 million tons $(25.6 \mathrm{mn} \mathrm{bbl})$ of oil from Saudi Aramco each year. Saudi Aramco might invest 45 percent, China 40 percent, and the remainder might come from South Korea. This deal would be the first direct Saudi Arabian investment in China.

Saudi Aramco is also acquiring 50 percent of the Greek refining and marketing company Motor Oil Helles, in Greece. The refinery has a capacity of $100,000 \mathrm{~b} / \mathrm{d}$ and 3 million barrels of crude oil storage. The deal, with a value of $\$ 700-750$ million, also includes a chain of 600 gasoline stations.

However, the Saudi's equity interests in foreign downstream operations tells less than half of the story. The Saudis only obtain equity interest in refineries for which they hold an agreement to supply 100 percent of the refinery's feedstock needs. Their policy goal is to establish a home for approximately one half of their production. The Saudis currently have supply agreements for approximately $1.35 \mathrm{mn} b / \mathrm{d}$ with foreign refineries in which they hold an equity position; this includes the Greek Motor Oil Helles deal. The Maoming refinery would account for another $100,000 \mathrm{~b} / \mathrm{d}$ of supply. Plus the Saudi domestic refining industry calls for between 1.75 and $2.0 \mathrm{mn} \mathrm{b} / \mathrm{d}$ of feedstock. Combined, these amount to supply arrangements totalling nearly $3.5 \mathrm{mn} \mathrm{b} / \mathrm{d}$. This is over 40 percent of current production but may exceed 50 percent of the Saudi production following the return of Iraq to the international petroleum market.

Saudi Arabia is also heavily involved in the international LPG (liquefied petroleum gas) market. During 1994, the Saudis exported LPG at the annual rate of 15 $\mathrm{mn}$ tonnes. They maintained this level of exports even while the domestic demand for butane for petrochemical feedstock increased by $1 \mathrm{mn}$ tonnes/year. The Saudis are the single largest exporter of LPG, and they effectively set the world price. That is, export prices everywhere in the world are generally based on the Saudi price plus freight. 
Worldwide exports of LPG amounted to roughly $46 \mathrm{mn}$ tonnes for 1994, so Saudi Arabia accounted for approximately 32 percent of total export trade. Japan imported 15.3 mn tonnes of LPG in 1994, also about 32 percent of worldwide trade. The Saudis supplied 46 percent of Japan's imports.

It is expected that Saudi Arabia will maintain its export capacity at around the 14$15 \mathrm{mn}$ tonnes/year level, while also satisfying domestic butane requirements. This level of LPG production will be facilitated by the Saudi move toward increasing the share of light crude oil production. Light crude oil tends to carry with it larger volumes of LPG than that associated with heavier crude oil.

These activities, in conjunction with domestic expansion plans for the refinedproducts export industry, suggest a deeper move into the products side of the business. Saudi Arabia has only limited plans to expand crude oil production capacity, since the currently claimed capacity of $10 \mathrm{mn}$ b/d exceeds the Saudi quota by $2 \mathrm{~m} / \mathrm{b} / \mathrm{d}$.

\section{Kuwait}

Kuwait is producing its crude oil within its OPEC negotiated quota of 2 million b/d. Kuwait's oil reserves were estimated to exceed 96 billion barrels at the start of 1995, with natural gas reserves of 52.9 trillion cubic feet. Table 4 shows that Kuwait has an R/P ratio of 130 years for crude oil at 1994 production levels and 333 years for natural gas produced at the 1993 rate.

Kuwait has stated publically that it will seek an increase in its quota of 200,000 $\mathrm{b} / \mathrm{d}$ for 1996. For domestic budgetary planning, Kuwait assumes its production will be at the $2.2 \mathrm{mn}$ b/d level for 1996. Even at this production rate, Kuwait's estimated reserves would last 120 years. Kuwait has also recently announced plans to increase production capacity to $3.0 \mathrm{mn}$ b/d by 2000 , from the current $2.4-2.5 \mathrm{mn}$ b/d level, and to $3.5 \mathrm{mn} \mathrm{b} / \mathrm{d}$ by 2005 . However, when Iraq reenters the international market, Kuwait may once again be pressured to constrain production. Kuwait's OPEC quota was $1.4 \mathrm{mn} \mathrm{b/d} \mathrm{in} \mathrm{July}$ 1990 , when Iraq's quota was $3.14 \mathrm{mn}$ b/d.

Chevron has won a three-and-a-half-year contract (finalized in August 1994) to provide consultancy services on managing the reservoir of the giant Burgen oil field. BP has had a similar arrangement since 1992, but with the Chevron deal, BP's activities will 
be limited to the smaller Minagish and Umm Gudair fields in western Kuwait. Amoco is in contention for a third contract, apparently for fields in the north. None of these contracts give the foreign firm entitlements to lift crude oil. They are fee-based technical service contracts.

In early March 1995, it was announced that bids would be invited from foreign companies to explore and produce in the Kuwaiti-Iraqi border region. A question yet to be resolved is whether the arrangements should be in the form of joint-venture or production-sharing terms. This will be decided by the Supreme Petroleum Council. There has been much debate regarding allowing foreign investors and operators into the upstream oil industry. The debate has even been joined by former energy ministers who argue for greater involvement by foreign companies. They also argue that fields other than those along the Iraqi border should be opened up.

Kuwait plans to increase its refined products exports and to increase participation in offshore, joint-venture refineries by entering into the Indian, Pakistani, and Thai markets. Domestically, Kuwait Petroleum Company (KPC) plans capacity expansions from $800,000 \mathrm{~b} / \mathrm{d}$ to "just below" $1 \mathrm{mn} \mathrm{b} / \mathrm{d}$ for its three refineries. KPC, Kuwait's national oil company, will expand its European capacity from the current $135,000 \mathrm{~b} / \mathrm{d}$ to about 300,000 b/d. In September 1994 Kuwait and Pakistan announced plans to spend some $\$ 1$ billion to construct a 120,000 b/d refinery in Pakistan's Baluchistan Province. While expansion plans and grass-roots facilities are always uncertain until the financing has been arranged and construction is under way, Kuwait's intention to expand its overseas activities is clear.

The combination of these capacity expansions and additions amounts to roughly $765,000 \mathrm{~b} / \mathrm{d}-200,000 \mathrm{~b} / \mathrm{d}$ of domestic export capacity, 400,000 b/d in Asia, and about $165,000 \mathrm{~b} / \mathrm{d}$ in Europe. If Kuwait intends to provide the crude oil (or even some fraction of it) as feed for this incremental capacity, it will have to reroute some of its current exports, or increase production, or both. There might be a link between Kuwait's insistence on an increase of its quota by $200,000 \mathrm{~b} / \mathrm{d}$ and its plans to increase the capacity of its export refineries by that capacity. If all of these expansions come to fruition, Kuwait will be among the most integrated producer nations.

Kuwait's export split between crude oil and refined products has been tilting. During 1994 there was a steady increase in the share of refined products in export 
volumes, while crude oil production (this would be wellhead production, not the OPEC quota "supply" amount) has been pretty steady at between $2.0 \mathrm{~b} / \mathrm{d}$ and $2.05 \mathrm{~b} / \mathrm{d}$ (Table 8).

Table 8. Kuwait's 1994 Crude Oil Production, Crude Oil Exports, and Refined Products Exports (million b/d)

\begin{tabular}{lccc}
\hline Month & Crude Production & Crude Exports & Products Exports \\
\hline January & 2.000 & 1.365 & 0.520 \\
February & 2.005 & 1.350 & 0.530 \\
March & 2.000 & 1.345 & 0.540 \\
April & 2.000 & 1.400 & 0.560 \\
May & 2.020 & 1.320 & 0.580 \\
June & 2.030 & 1.310 & 0.600 \\
July & 2.050 & 1.270 & 0.660 \\
August & 2.050 & 1.260 & 0.670 \\
September & 2.050 & 1.250 & 0.680 \\
October & 2.030 & 1.230 & 0.680 \\
November & 2.040 & 1.230 & 0.690 \\
December & 2.040 & 1.240 & 0.680 \\
\hline
\end{tabular}

Kuwait Oil Tanker Company (KOTC) currently has a fleet of 37 ships with a total tonnage of 4 million deadweight tons (dwt). Seven of these ships are crude oil carriers. Two of the crude oil carriers, each at 295,000 dwt, are being converted into hybrid crude/products carriers. KOTC scrapped one of its biggest very large crude carriers (VLCC), the 339,106 dwt Bubiyan, in November 1994. However, KOTC has been authorized to order three more VLCCs, each of $280,000 \mathrm{dwt}$. The expansion of KOTC's carrier fleet is in response to KPC's rapidly rising charter costs.

KPC is selling its U.S.-based oil- and gas-producing properties of its Santa $\mathrm{Fe}$ International subsidiary. Output from these properties is about $5,200 \mathrm{~b} / \mathrm{d}$ of oil and 124 
million cubic feet/d of gas. The properties are located primarily in the Gulf of Mexico, Kansas, and Oklahoma. However, Santa Fe's North Sea holdings will be unaffected by this sell-off.

This sell-off does not appear to indicate that Kuwait is backing out of foreign oil and gas investments. KPC has indicated an interest in expanding its presence in other foreign oil and gas markets. Oil Minister Abd al-Muhsin al-Midaj announced in November 1994, while traveling in Thailand, KPC's interest in acquiring a share in either an existing refinery or a new refinery planned for Khanom in the Krabi District of Nakhon Si Thammarat Province.

Kuwait Foreign Petroleum Exploration Company (Kufpec) is also expanding its overseas operations. It expects that 1995 output of $15,000 \mathrm{~b} / \mathrm{d}$ from fields in Egypt, Indonesia, Australia, Tunisia, and Congo will double as a result of planned investments. Investment expenditures may also include the development of a field in Yemen.

The term-contract pricing mechanisms for Kuwaiti crude oil are similar to those for Saudi Arabia. The European-bound crude oil has a term-contract price that is tied to Brent, forty days after loading, and an adjustment factor that accounts for transport and quality difference. The adjustment factor for Kuwaiti oil is larger (a bigger negative) than that for Arab Light, which reflects in part the fact that Kuwaiti crude oil is $31^{\circ}$ API, compared with the $34^{\circ}$ API for Arab Light. The adjustment factors for Kuwaiti export crude oil and Arab Medium are typically much closer, reflecting the fact that both are rated as $31^{\circ}$ API. The point-of-sale basis is f.o.b. Kuwait. For January 1995, the Kuwait adjustment factor was minus $\$ 1.70$, compared with the minus $\$ 1.15$ for Arab Light.

For the U.S. market, the formula price is tied to WTI, on the date of delivery, with an adjustment factor. The point-of-sale basis for this formula price is the U.S. Gulf. A comparison between Kuwaiti crude oil into the U.S. market and Arab Light into the same market is difficult because of the differences in the formulas. A simple comparison between the adjustments factors does not provide much insight. The Arab Light formula has an f.o.b. point-of-sale and is set 50 days after loading. Whereas, the Kuwait formula has a U.S. Gulf point-of-sale and is set at the date of delivery. The adjustment factor for Kuwait, for January 1995, was minus \$1.75, compared with Arab Light's factor of minus $\$ 2.35$ and minus $\$ 2.90$ for Arab Medium. 
The Far East formula for Kuwaiti crude oil, like that for the Saudi Arabian crude oils, is based on the f.o.b. point-of-sale, the average of the spot prices for Oman and Dubai, and an adjustment factor, with no time adjustment for loading. For January 1995, the Kuwait formula adjustment factor was minus $\$ 0.50$, compared with the plus $\$ 0.50$ for Arab Light minus $\$ 0.40$ for Arab Medium.

\section{Iraq}

Iraq's production has been constrained by United Nations sanctions, which followed the 1990 Gulf War. The U.N. sanctions on Iraq prohibit Iraq from exporting its crude oil until it has fully satisfied several U.N. Resolution conditions. These conditions include the full recognition of Kuwait and the provision of information regarding weapons systems. Under current policies, until it satisfies the resolution conditions, Iraq is allowed only to produce crude oil for its own domestic requirements and a small amount for export to Jordan.

In July 1990, just prior to the war, Iraq's OPEC quota was at $3.14 \mathrm{mn} \mathrm{b/d}$, at par with Iran. The current OPEC quota, reported in Table 3, is $400,000 \mathrm{~b} / \mathrm{d}$. Iraq has never accepted this level and has generally ignored it. Iraq claims that the July 1990 quotas were the last ones without outside pressures being brought to bear on the members of OPEC, even though Iraq had been heavily pressuring Kuwait (Kuwait's July 1990 quota was set at $1.4 \mathrm{mn}$ b/d). The July 1990 meeting was the last time that Iraq participated fully in the quota setting process.

Iraq's reserves are estimated at 100 billion barrels of crude oil and 109 trillion cubic feet of natural gas. (Not reported in Table 4 are recent estimates of Iraqi reserves of 112 billion barrels of oil and 106 trillion cubic feet of gas. These estimates were presented at an oil and gas seminar held in Baghdad in March 1995.) Iraq's production has been in the area of $520,000 \mathrm{~b} / \mathrm{d}$. There are claims that the production has actually exceeded $700,000 \mathrm{~b} / \mathrm{d}$. Such claims usually accompany assertions that Iraq is cheating on the sanctions and placing crude oil into the international market. Alternatively, the Iraqis claim that the level of production is just high enough to meet domestic refining needs and permitted exports, via tanker trucks, to Jordan. They also assert that some of the apparent overproduction is due to the production of crude oil to extract required volumes of associated natural gas. Excess crude oil is then said to be reinjected into the reservoir. 
This may be a rare, if not unique, example where crude oil is used essentially to pressurize a reservoir for natural gas production.

At the current $520,000 \mathrm{~b} / \mathrm{d}$ production rate, Iraq's R/P ratio stands at 527 years. If the production rate were to return to the $3 \mathrm{mn} b / \mathrm{d}$ range, the $\mathrm{R} / \mathrm{P}$ ratio would drop to 91 years, which is still a very substantial reserve. For natural gas, based on 1993 production levels, the $\mathrm{R} / \mathrm{P}$ ratio is over 1,000 years.

Iraq states that it has no intention to flood the world crude oil market once U.N. sanctions are lifted. While not at all unusual, Iraq has also made statements recently that would appear to contravene its stated intention to not flood the market. Iraq has continued to hold that the $400,000 \mathrm{~b} / \mathrm{d}$ OPEC quota will be ignored and has said that it will produce "at will" once the sanctions are removed, until it reaches parity with Iran, whose current OPEC quota is $3.6 \mathrm{mn}$ b/d. Initial capacity, upon removal of the sanctions,

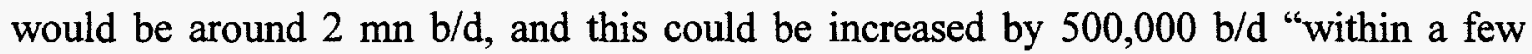
weeks." Output capacity can be restored to $3.2 \mathrm{mn} \mathrm{b/d}$ within fourteen months. Such statements might be an extension of the long existing rivalries between Iraq and Iran, Iraq and Kuwait, and Iraq and Saudi Arabia.

The statements are likely a means by which the Iraqis are putting these three neighbors on notice that they should plan to cut production once the U.N. sanctions are removed. Specifically, a paper presented by officials of the Iraqi Oil Ministry, at the international oil seminar held in Baghdad in early March 1995, included the following under the heading "Market Situation: Regaining Production Quota":

"Iraq has been one of the leading OPEC members and for its part has done its utmost to adhere strictly to the Organization's decisions on production and prices. Iraq is known for its constructive role in shaping the Organization's policy since its creation in Baghdad in 1960. In return, Iraq expects the Oranization and its members to act responsibly and honor earlier commitments including those made before the aggression relating to its fair production quota within the OPEC ceiling and subsequent resolutions which recognize Iraq's right to produce its natural quota (as stated in July 1990 and adjusted upwards since then) without the need to 
refer to the conference, and call upon other members to adjust their production levels in a fashion consistent with market requirements.",

The Iraqis might be able to achieve a significant increase in the rate of production in a very short time period, but some doubt whether or not Iraq will have adequate access to export facilities once sanctions are removed. Iraq has not yet attempted to ready the export pipeline running through Turkey; it will await the removal of the sanctions. The pipeline requires flushing and maintenance. The line still contains crude oil from 1990. Without repairs to a damaged pump station, the capacity of the line is $1.2 \mathrm{mn} b / \mathrm{d}$. Upon completion of the repairs, and the flushing of the line, it would have the capacity to move $1.6-1.8 \mathrm{mn} \mathrm{b} / \mathrm{d}$ into the export market.

The port of Mina al-Bakr, on the Gulf coast, is reported to be limited currently to $500,000 \mathrm{~b} / \mathrm{d}$ of capacity. However, the Iraqis claim that the port has a capacity of $1.2 \mathrm{mn}$ $\mathrm{b} / \mathrm{d}$. This looks realistic given history. Thus, even if the capacity is constrained currently to $500,000 \mathrm{~b} / \mathrm{d}$, it is likely that the capacity could be expanded quickly. Therefore, prior to repairing the pipeline pump station, the export capacity is around $2.4 \mathrm{mn} \mathrm{b} / \mathrm{d}$, and could be raised to $3 \mathrm{mn} b / \mathrm{d}$ with the repairs. This would provide Iraq with more than enough capacity to handle export volumes.

While Iraqi crude oil is currently excluded from international markets, there are published term-contract formulas for the three primary markets-Europe, the United States, and the Far East. The formula for Europe has a point-of-sale at Ceyhan, Turkey, is tied to Brent, and takes effect 5 days after loading. Ceyhan, Turkey is near the Dortyol terminus of the Iraq-Turkey pipeline. For the U.S. market, the point-of-sale is f.o.b., the price is tied to Alaska North Slope priced in the U.S. Gulf, and takes effect 5 days after loading. And for the Far East, the point-of-sale is the Red Sea, the price is based on the average of Oman and Dubai spot prices, with no loading-day adjustment. Since none of this crude oil has legally entered the international market, no adjustment factors have been recorded.

Even while the Iraqi crude oil is banned from the international market by U.N. sanctions, the Iraqis are courting foreign oil companies for investment and assistance with their upstream crude oil production development. Generally, Iraq's position is that the foreign companies may enter the upstream sector "within the framework of production

\footnotetext{
${ }^{5}$ The paper, "The Iraqi Oil Industry: Present Conditions and Future Prospects," is reprinted in the Middle East Economic Survey, March 20, 1995, pp. D1-D13.
} 
sharing deals, joint ventures, or services contracts, according to taste." The Iraqis have forecast that the world oil market will need $5 \mathrm{mn} \mathrm{b/d}$ of their production by 2000 , increasing to $6 \mathrm{mn}$ b/d by 2010 . Negotiations have been under way with several French companies and with the Russians. U.S. companies have not been part of this process and were not invited to the recent oil and gas seminar in Baghdad. This apparent liberal policy toward foreign investors may be the result of Iraq finding itself in a rather weak position. If so, the openness could disappear soon after Iraq feels it is in a stronger position.

\section{United Arab Emirates (UAE)}

The UAE is a federation of seven emirates, formed December 2, 1971 (Ras al-Khaimah joined in early 1972), which became independent of Great Britain. Abu Dhabi and Dubai are the largest oil and gas producers, and their commercial success is reflected in their federation leadership positions, with the President of the UAE being the ruler of Abu Dhabi and the Vice President being the ruler of Dubai. It is a true federation, in that each emirate sets its own policies. The UAE has the fourth largest estimated crude oil reserves of the seven Persian Gulf Arab nations and the second largest natural gas reserves.

The UAE is a member of OPEC, and its crude oil production quota is 2.161 million $\mathrm{b} / \mathrm{d}$. As Table 3 shows, the UAE has overproduced between 20,000-40,000 b/d since November 1994. The proved reserves of crude oil as of January 1, 1995, amount to over 98 billion barrels, and the natural gas reserves exceed 200 trillion cubic feet. Table 4 shows that at current production levels these reserves will last over 120 years for oil and 230 years for gas.

Abu Dhabi's liquefied natural gas (LNG) facilities at Das Island, operated by Abu Dhabi Gas Liquefaction Company (ADGAS), have recently doubled in output-from 2.5 million tonnes per year to 5.0 million tonnes per year. All of the LNG export volumes are sold to the Tokyo Electric Power Company under a series of long-term contracts. These export volumes account for about 24 percent of total UAE natural gas consumption in 1993, and the doubling of export LNG volumes is expected to increase the share to over 45 percent. Nearly two-thirds of the UAE's primary energy usage is satisfied with natural gas. 
While ADGAS's capacity is contractually obligated to its single Japanese customer, it has shown aggressiveness and flexibility by arranging to export three spot cargoes of LNG to Belgium and France. The deals were made with France's Gaz de France and Belgium's Distrigaz for the export of 8.4 bcf of LNG, to be delivered in three cargoes during the 1994-1995 winter. The price was somewhere between the c.i.f. Europe and c.i.f. Japan LNG prices of between $\$ 2.80$ to $\$ 3.10$ per mn Btu.

Abu Dhabi, which produces over 80 percent of the UAE crude oil, would like to see the UAE's OPEC quota raised. Abu Dhabi says it currently has sustainable production capacity of $2.6 \mathrm{mn} \mathrm{b} / \mathrm{d}$, with plans to expand this to $3.0 \mathrm{mn}$ b/d by the end of the decade. The private foreign partners in the upstream operations are pressing for higher production flows. We noted earlier that investment by private foreign companies could lead to pressure to increase production when rates of return decline.

Abu Dhabi is also expanding its refining capability and establishing a presence in the petrochemical industry. The Abu Dhabi Supreme Petroleum Council has given the go-ahead to the Abu Dhabi National Oil Company (ADNOC) to significantly expand and upgrade the existing refinery at Ruwais. The expansion program at Ruwais will double the distillation capacity to $270,000 \mathrm{~b} / \mathrm{d}$, and it will add a new processing facility for $135,000 \mathrm{~b} / \mathrm{d}$ of condensate. Upgrading of the conversion units will include the addition of a new $40,000 \mathrm{~b} / \mathrm{d}$ hydrocracker and a $36,000 \mathrm{~b} / \mathrm{d}$ visbreaker. Current planning also calls for the addition of facilities to produce $85,000 \mathrm{~b} / \mathrm{d}$ of unleaded gasoline. In addition, ADNOC is planning to construct a polyethylene plant. This portion of the downstream facilities expansion plan is as yet not clearly defined; the UAE is looking for foreign investors and guidance on the final configuration. The completion of all of the upgrades and expansions is planned for 1999.

Dubai is also inclined to expand into the downstream and petrochemical sectors. A new 500,000 tons/year MTBE (methyl tertiary butyl ether) plant has just been completed. Unfortunately this plant is coming on line at a time when MTBE prices are severely depressed. Sharjah has also shown an interest in private-sector production of methanol and MTBE.

The spot price of Dubai crude oil is used as a market benchmark, typically in conjunction with Omani crude oil, for many of the Mideast crude oils marketed in the Far East. Its benchmark role is weakening, however, owing to the decline in the volume of production. As noted in Table 4, Dubai's production dropped to an average of 340,000 
b/d in 1994. Dubai has no refining capacity and limited storage capacity. This tends to make Dubai prices reflect short-term market trends.

The term-contract price for Abu Dhabi crude oil is established as a retrospective or retroactive price, tied to the price of Dubai in the previous month.

\section{Qatar}

Qatar has modest crude oil reserves, by Gulf standards, but it is endowed with the largest estimated natural gas reserves on the Arab side of the Gulf-Iran's estimated reserves are nearly three times larger than Qatar's. Crude oil reserves are estimated to be 3.7 billion barrels, while the natural gas reserves are estimated to be 250 trillion cubic feet. As reported in Table 4, the existing crude oil reserves have an R/P ratio of about 25 years at the 1994 rate of production. The natural gas reserves have an $\mathrm{R} / \mathrm{P}$ ratio of over 500 years at the 1993 rate of production.

Qatar is a member of OPEC and has a production quota of $378,000 \mathrm{~b} / \mathrm{d}$. Production averaged 399,000 b/d during 1994 (see Table 3) - this is "supply" according to the OPEC definition, but Qatar has increased the rate to around $420,000 \mathrm{~b} / \mathrm{d}$ for January and February 1995.

Qatar is open to foreign investment in its upstream production sector. Qatar entered into a production sharing agreement with Pennzoil Qatar Inc., a subsidiary of Houston-based Pennzoil Exploration and Production, for developing offshore Block 8. The area is located 75 kilometers to the east of the peninsula and surrounds the Bul Hanine and Maydan Mahzam oil fields. This activity reflects Qatar's desire to maintain or expand current production capacity.

Qatar's primary focus is on the world LNG market. It plans to export as much as $16 \mathrm{mn}$ tonnes/year ( $\mathrm{t} / \mathrm{y})$ —approximately 780 billion cubic feet per year (bcf/y)—by 2010 . This level would constitute over 15 percent of the world LNG export capacity that is currently counted as existing, firm, and likely to be on line in 2010. The size of Qatar's natural gas resource is sufficiently large that even the increment $780 \mathrm{bcf} / \mathrm{y}$, added to its 1993 level of production, would result in an R/P ratio of nearly 200 years.

There are currently three LNG projects planned. The Qatar Gas Liquefaction Company (Qatargas) plans to come on line in October 1996, with a production capacity 
of $6 \mathrm{mn} \mathrm{t} / \mathrm{y}$. The partnership shares differ between the upstream and downstream portions of the project, but foreign investors are well represented in both portions. The shareholdings in the upstream portion are: Qatar General Petroleum Corporation (QGPC), 65 percent; Total, 20 percent; Mobil, 10 percent; Marubeni, 2.5 percent; and Mutsui, 2.5 percent. The liquefaction and downstream shares are: QGPC, 65 percent, Total, 10 percent; Mobil, 10 percent; Marubeni, 7.5 percent; and Mitsui, 7.5 percent.

Chubu Electric, Japan, signed a 25-year agreement in 1992 for $4 \mathrm{mn}$ t/y of LNG from the Qatargas facilities, with first delivery scheduled for January 1997. Chubu also held an option for an additional $2 \mathrm{mn} t / \mathrm{y}$. The remaining $2 \mathrm{mn}$ t/y were contracted for by seven Japanese electricity and gas utilities, including Tokyo Electric Power Company. They signed a 25 -year agreement in January 1995, and by so doing precluded Korea Gas Corporation from entering into the project. This might have been a move on the part of the Japanese to dedicate the entire output of the Qatargas project to Japan.

Two additional LNG projects are under consideration. The joint-venture project, Ras Laffan LNG (Rasgas), was established in August 1992 with the combination of QGPC (70 percent) and Mobil (30 percent). The agreement contained the proviso that the venture would have the exclusive rights to the next $10 \mathrm{mn}$ t/y of LNG export capacity in Qatar. However, to date, Mobil has not entered into any sales and purchase agreements for any of this capacity. There are signed memoranda of understanding (MOU) with Korea Gas Corporation, Taiwan's Chinese Petroleum Corporation, China, Turkey's Botas, and India's Essar. However, the MOUs are not binding, and without binding sale and purchase contracts financing will not be forthcoming.

In January 1995, Enron, another U.S. energy company, signed a letter of intent with QGPC to develop a $5 \mathrm{mn}$ t/y LNG facility, also at Ras Laffan, to serve Mediterranean and Indian markets. Because of the exclusivity clause in the QGPC-Mobil Rasgas agreement, QGPC has officially requested Mobil to waive this right. The Enron project would deliver LNG to Indian power stations in which it holds an equity interest. Enron also plans to export LNG to Israel and Jordan. Mobil is reluctant to relinquish its exclusive right for two reasons. First, Mobil is concerned that a third LNG project would overexpose Qatar within the international financial markets. Second, it is concerned that Enron would encroach on its market in India. Mobil's position, lacking sales and purchase agreements, is further weakened by Enron's commitment to buy all of the LNG for its own account, f.o.b. Ras Laffan. No resolution is at hand, but Mobil is expected to 
eventually waive the exclusivity clause, but only after receiving assurances of market limits on Enron in India.

An additional export option is via pipeline. There are discussions between Qatar and Crescent Petroleum (a private Sharjah company) to develop a natural gas pipeline to supply Pakistan. The $1,600 \mathrm{~km}$ line would originate in Qatar and pass through the UAE to reach Pakistan. This system appears to be a competitor with the proposed IranPakistan pipeline project.

Qatar's crude oil term-contract price formula is tied to the Oman MPM (Ministry of Petroleum and Minerals) price, as opposed to the Oman spot price used in most other Gulf formulas for Far-East crude oil markets. The Oman MPM is an assessment price for term crude oil set by the Omani ministry. Qatar's formula, like Abu Dhabi's, is retrospective. There are no published formulas for Qatari crude oil for either Europe or the United States, neither have there been any crude oil imports into the United States originating from Qatar during the past two years.

\section{Bahrain}

Bahrain has very limited crude oil and natural gas reserves. At the beginning of 1995, it was estimated that there were 210 million barrels of oil and just 5 trillion cubic feet of natural gas. Bahrain is not a member of OPEC and thus has no quota limitation. Bahrain has been reported to have an average production of 105,000 b/d during 1994 . However, Bahrain's production from its own fields was approxiamtely $40,000 \mathrm{~b} / \mathrm{d}$; the 60,000 -plus $\mathrm{b} / \mathrm{d}$ additional volumes are the result of an allocation arrangement between Bahrain and Saudi Arabia from a joint offshore field. Because of the small size of its reserves, this production level would deplete the resource in just over five years if the full $105,000 \mathrm{~b} / \mathrm{d}$ is counted against these reserves; the R/P ratio is 14 years when accounting for the 40,000 $\mathrm{b} / \mathrm{d}$ production from Bahrain's own fields. The natural gas reserves will be depleted in 19 years at the 1993 rate of production, if no additions to reserves are made. Since natural gas is used in both electricity and metal plants, the limitation on domestic reserves of gas may become a problem for Bahrain in the future.

While Bahrain is the only Gulf nation with an investment law that permits 100 percent foreign equity in Bahraini companies, there is no current activity in the oil sector that would lead to such ownership. The Sitra oil refinery is owned jointly by the Bahraini 
government ( 65 percent) and Caltex ( 35 percent). The Bahrainis are not planning to enter the race to export natural gas because of their own domestic requirements. However, they do have a joint-venture petrochemical development. The Gulf Petrochemical Company - owned in equal shares by government firms from Bahrain, Kuwait, and Saudi Arabia-produces ammonia and methanol. The company hopes to a construct a 561,000 t/y urea plant at its facilities in Bahrain at a cost of $\$ 100 \mathrm{mn}$, with a scheduled completion date of 1997.

In oil-related activity, the Arab Shipbuilding \& Repair Yard (ASRY), which is located in Bahrain, is doing good business. ASRY is sponsored by OAPEC and is another example of the cooperative economic development activities carried out under one of the region's Arab umbrella organizations. ASRY reported that revenues for the first six months of 1994 were up 10 percent over the same period in 1993, and it had won a contract to repair three Petrobras VLCCs.

Bahrain Petroleum Company (BAPCO), the Bahrani government, and Caltex have renewed their commitment to modernize and upgrade the BAPCO Sitra refinery, although it is rumored that Caltex does not want the upgrade. Current distillation capacity of $250,000 \mathrm{~b} / \mathrm{d}$ will remain unchanged, but the product mix will change, with fuel oil falling to 10-12 percent of output from the current 26 percent. The yields of middle distillates and gasoline will expand.

The Sitra refinery processed an average of $247,300 \mathrm{~b} / \mathrm{d}$ during 1993, with 206,700 $\mathrm{b} / \mathrm{d}$ of that volume originating from Saudi Arabia and transported via pipeline. The remainder of the feedstock requirements were supplied from Bahraini production. The refinery is focused on the export market, and an average of $243,400 \mathrm{~b} / \mathrm{d}$ of products are exported.

Since it does not sell crude oil, Bahrain does not have a published term-contract formula for its crude oil.

\section{Oman}

Oman is not a member of either OPEC or OAPEC and is therefore not constrained by any public production agreement. By Gulf standards, Oman has modest proved reserves of both crude oil and natural gas. The January 1, 1995, estimate for oil was 4.8 billion 
barrels, and the estimate for natural gas was 22.2 trillion cubic feet; it was noted earlier that Oman now claims it has 24 tcf of proved reserves. Table 4 shows that at the 1994 rate of production $(800,000 \mathrm{~b} / \mathrm{d})$ the $\mathrm{R} / \mathrm{P}$ ratio is 16.5 years for oil, and at the 1993 rate of production ( $98 \mathrm{bcf} / \mathrm{y}$ ) the R/P ratio is over 225 years for gas. The government of Oman claims that it is currently producing crude oil at a rate of around $828,000-830,000 \mathrm{~b} / \mathrm{d}$, while the International Energy Agency argues that Oman is producing at more like $850,000 \mathrm{~b} / \mathrm{d}$.

Oman plans to spend $\$ 4$ billion over the next five years to develop its crude oil reserves and production capacity further. Exploration plans call for stepping out from previously explored areas, as well as going deeper than before. New technologies are helping to keep the costs of maintaining and expanding productive capacity down, so that costs today are no higher than five years ago. Oman makes heavy use of horizontal drilling technology, with 70 percent of planned new wells being of this type. While the horizontal wells costs 50 percent more than conventional wells, they typically provide three times the productivity.

Oman plans to enter the natural gas export market. It is currently considering an LNG facility that targets Far-East markets and a subsea natural gas pipeline project to India. The LNG project is designed to produce $6.2 \mathrm{mn}$ tonnes/year ( $302 \mathrm{bcf} / \mathrm{y})$, with a planned start-up date of 2000. In February 1995, the Korea Gas Company signed a letter of intent with the Oman Liquefied Natural Gas Company (OLNGC) for the purchase of 3 $\mathrm{mn}$ tonnes/year for a 25 -year period beginning with the start-up date. The OLNGC is a joint venture made up of the Omani government $(51 \%)$, Shell $(34 \%)$, Total $(6 \%)$, Mitsubishi (3\%), Mitsui (3\%), Partex (2\%), and Itochu (1\%). The upstream portion of the project will be wholly owned by the Omani government.

The Omani-Indian pipeline project is considered a "pipe dream" by many in the industry. It is one of three pipeline export proposals; the other two are the Qatar-Crescent and one from Iran. Nevertheless, Oman's continued pursuit of gas export projects like this emphasizes its firm intent to find the best markets possible for its growing natural gas resource. The pipeline, if completed, would be an engineering marvel. The project calls for a two-phase development program to lay a $24 \mathrm{inch}, 1 \mathrm{bcf} / \mathrm{d}$ undersea line at depths reaching 3,500 meters. The plan includes an onshore pipeline to deliver natural gas from Central Oman to the Omani coast, where a compressor station would boost the line pressure to $6,000 \mathrm{psi}$ to move the gas 1,130 kilometers to India. The first phase would be completed by mid-1999, with a second 24 inch line being brought into service by 2001 . 
The first phase is estimated to cost $\$ 2.7$ billion, and the total project cost is estimated at $\$ 5$ billion. However, since no such line has ever been constructed before, we look at these estimates as representing at best a central value in a distribution of possible costs that is skewed significantly to the high side.

With the recent claims of increased proved reserves, i.e., 24 tcf, the Omani government also claims that both the LNG and the subsea pipeline projects can be physically supported. However, the financial requirements for both would be too high. It is expected that if a choice has to be made between the two projects, the LNG project will be preferred. It will enhance the domestic economy much more than the pipeline project.

While Oman focuses its attention on its natural gas export infrastructure, it also is involved in foreign oil investments. The Oman Oil Company is to be a partner, with the Government of the Russian Federation and the Government of Kazakhstan, in the construction of the Caspian oil pipeline between the Tengiz oil field in Kazakhstan and the Black Sea. It is also investigating possible involvement in two joint-venture refineries in India.

The Omani government-set term-contract price for crude oil has typically been set retroactively against the benchmark Dubai crude oil plus a premium. In past years the premium for Oman ( $\left.35^{\circ} \mathrm{API}\right)$ crude oil over Dubai $\left(31^{\circ} \mathrm{API}\right)$ typically averaged around $\$ 0.68$ per barrel; however, for 1994 the average was in the mid- $\$ 0.40$ per barrel range. The differential varied from a high of about $\$ 0.98$ per barrel to as low as $\$ 0.10$ per barrel.

\section{Conclusion}

The general conclusion is that overproduction will continue to occur, and as a result prices will remain relatively soft. The seven Gulf Arab states have shown through other oil sector activities that they intend to broaden their investments and participation level in downstream and petrochemical operations. Moreover, they have shown an increased openness to foreign investment throughout much of their domestic oil sector activities.

Each of the seven Gulf Arab nations is looking both inward and outward for expansions of its oil-related industries. The five OPEC members continue to be concerned with developing policies that will stabilize the world price of oil and their market share, but the opening of their upstream and downstream oil sectors to foreign 
investors and their own investments in domestic and foreign downstream capacity is likely to place continued upward pressure on the level of production. Moreover, the eventual return of Iraq to the international market will place significant strain on the Gulf producers, including Iran.

The resulting strain on these countries will be exacerbated by their persistent government budget deficits. This will tend to speed the movement, already under way, toward privatization of domestic industries.

More specifically, (1) Each of the Gulf Arab states intends to invest in crude oil production capacity. The purpose of the investment is to maintain current production levels - at a minimum - but typically the goal is to expand output to meet expected future demand and revenue requirements. Each is open to foreign participation, but the Saudis will limit it to the Shaybah field at most.

(2) All intend to expand downstream and petrochemical capacities with the goal of increasing export volumes and capturing the value added through the manufacturing process. Oman and Bahrain are open to foreign investment in refining; Oman and the UAE are open to foreign investment in oil marketing; and all but Iraq are open to foreign investment in petrochemicals.

(3) Qatar, Oman, and to a lesser extent the UAE intend to actively participate in the natural gas export market. Much of the focus is on LNG exports into the fast growing Far East markets, but pipeline and LNG exports to South Asia are also targeted. All three are open to foreign investment in natural gas exports.

(4) Saudi Arabia, Kuwait, and Oman are each pursuing policies that focus on investing in foreign oil sectors. Much of this investment is in downstream sectors, but it also reaches upstream and transport sectors. 


\section{APPENDIX A}

\section{Arab-Islamic Organizations}

(The Persian Gulf Arab Nations are highlighted.)

\section{Arab Bank for Economic Development in Africa (ABEDA)}

aim to promote economic development

members (17 plus the Palestine Liberation Organization) Algeria, Bahrain, Egypt, Iraq, Jordan, Kuwait, Lebanon, Libya, Mauritania, Morocco, Oman, Qatar, Saudi Arabia, Sudan, Syria, Tunisia, the UAE, Palestine Liberation Organization. Note: These are all the members of the Arab League except Djibouti, Somalia, and Yemen

\section{Arab Fund for Economic and Social Development (AFESD)}

aim to promote economic and social development

members (20 plus the Palestine Liberation Organization) Algeria, Bahrain, Djibouti, Egypt (suspended from 1979 to 1988), Iraq, Jordan, Kuwait, Lebanon, Libya, Mauritania, Morocco, Oman, Qatar, Saudi Arabia, Somalia, Sudan, Syria, Tunisia, the UAE, Yemen, Palestine Liberation Organization

\section{Arab League (AL)}

aim to promote economic, social, political, and military cooperation members (20 plus the Palestine Liberation Organization) Algeria, Bahrain, Djibouti, Egypt, Iraq, Jordan, Kuwait, Lebanon, Libya, Mauritania, Morocco, Oman, Qatar, Saudi Arabia, Somalia, Sudan, Syria, Tunisia, the UAE, Yemen, alestine Liberation Organization 


\section{Arab Monetary Fund (AMF)}

aim to promote Arab cooperation, development, and integration in monetary and economic affairs

members (19 plus the Palestine Liberation Organization) Algeria, Bahrain, Egypt, Iraq, Jordan, Kuwait, Lebanon, Libya, Mauritania, Morocco, Oman, Qatar, Saudi Arabia, Somalia, Sudan, Syria, Tunisia, the UAE, Yemen, Palestine Liberation Organization

\section{Council of Arab Economic Unity (CAEU)}

aim to promote economic integration among Arab nations

members (11 plus the Palestine Liberation Organization) Egypt, Iraq, Jordan, Kuwait, Libya, Mauritania, Somalia, Sudan, Syria, the UAE, Yemen, Palestine Liberation Organization

\section{Economic and Social Commission for Western Asia (ESCWA)}

aim to promote economic development as a regional commission for the UN's Economic and Social Council

members (12 plus the Palestine Liberation Organization) Bahrain, Egypt, Iraq, Jordan, Kuwait, Lebanon, Oman, Qatar, Saudi Arabia, Syria, the UAE, Yemen, Palestine Liberation Organization

\section{Gulf Cooperation Council (GCC)}

aim to promote regional cooperation in economic, social, political, and military affairs

members (6) Bahrain, Kuwait, Oman, Qatar, Saudi Arabia, the UAE 


\section{Organization of the Islamic Conference (OIC)}

aim to promote Islamic solidarity and cooperation in economic, social, cultural, and political affairs

members (47 plus the Palestine Liberation Organization) Afghanistan (suspended), Albania, Algeria, Azerbaijan, Bahrain, Bangladesh, Benin, Brunei, Burkina, Cameroon, Chad, Comoros, Djibouti, Egypt, Gabon, The Gambia, Guinea, Guinea-Bissau, Indonesia, Iran, Iraq, Jordan, Kuwait, Kyrgyzstan, Lebanon, Libya, Malaysia, Maldives, Mali, Mauritania, Morocco, Niger, Oman, Pakistan, Qatar, Saudi Arabia, Senegal, Sierra Leone, Somalia, Syria, Tajikistan, Tunisia, Turkey, Turkmenistan, Uganda, the UAE, Yemen, Palestine Liberation Organization

observers (4) Kazakhstan, Mozambique, Nigeria, "Turkish Republic of Northern Cyprus"

Source: Factbook 1994, Central Intelligence Agency. 